\title{
Critical Evaluation of Contemporary Theories of Child Development and How These Inform the Work of Early Childhood Educators as Pedagogical Leaders
}

\author{
Wei Liu \\ Education Faculty \\ Monash University \\ 100 Clyde Rd, Berwick VIC 3806 Australia \\ wliu88@student.monash.edu
}

\begin{abstract}
Early childhood education has been stated importance in many government policy agendas. In Australia, the expected learning outcomes for children aged birth to five years are outlined in Early Years Learning Framework (EYLF). This article using contemporary theories' perspectives to provide theoretical scaffolding on children's development, relationship between play and learning are discussed in each theory lens. The author draws from contemporary theories' knowledge to support early years' educators using these theories as a guide in their daily pedagogical practice.
\end{abstract}

Keywords-early childhood education; play and learning; developmental theory; socio-cultural theory; poststructural theory; pedagogy

\section{INTRODUCTION}

This article uses an observation of children's play to propose how to use contemporary theories to analysis and interpret children's play and learning. Using three predominant theories-developmental, socio-cultural and poststructural theories to provide theoretical scaffolding, the discussion include: using Piaget's cognitive theory to observe children's play stages, understanding Vygotsky's cultural tools concept and recognizing the importance of ZPD in early years education when educators scaffolding children's play and learning, as well as understanding that we too must be open to change and take child's perspectives when using poststructural concepts to analysis children's play and behaviours. Further, the multiple perspectives on the relationship between play and learning are also discussed in each theory lens. Throughout, I use Early Years Learning Framework (EYLF) to reflect my analysis and discussion because EYLF assists educators to provide young children with opportunities to maximise their potential and develop a foundation for future success in learning [1]. The rest of this article reflects my understanding of these three theories and the strengths and limitations especially in relation to responding to EYLF are discussed finally.

\section{OBSERVATION}

Martin is a three and half-year-old boy at the childcare centre. He likes to play with other children in role-play area, but he always crosses alongside the social skills. He was frequently aggressive, the other children were afraid of him, and they did not like to play with him. Martin was often unhappy. Jack (four-year-old), Lexi (four-year-old).

Jack and Lexi were in the role-play area. Lexi were holding a doll. Martin walked into the role-play area and looked inside.

Martin: how many people are there? Two. I can play there.

No verbal response. But Jack and Lexi looked at Martin when he spoke.

Martin: I'm going to be a Daddy.

Jack: No, I'm daddy and Lexi is mum.

Martin: There can be two daddies.

Jack: No.

Lexi: No, boy can marry girl, but boy can not marry boy. Not in Australia, that is not fair.

Martin stood there for a while; he started to rifle through the dressing-up box for costumes.

He found a dog head-dress, tail and tow gloves, he put these on.

Jack: Hello, doggy.

Martin: Ruff, ruff.

Martin crawled away on all fours.

Lexi laughed and said: come here, doggy, Are you hungry?

Martin crawled to Lexi.

Martin sat down and the whole family began having their breakfast. 


\section{THEORETICAL ANALYSES AND INTERPRETATIONS}

\section{A. Developmental lens}

Developmental theories are about "understanding how children learn and grow" [2, p.4]. Piaget's cognitive theory provides what 'stages' of development children pass through at certain ages it guides and gives meaning to what we see -helps educators to interpret behavioral observation[3].

Piaget viewed when children are at age 3-4, they are active agents in shaping their own development [4]; He emphasized that children are not simply blank slates who passively and unthinkingly respond to whatever the environment offers them. That is, children's behavior and development are motivated largely intrinsically (internally) rather than extrinsically [4]. For example, when Martin got refused response for being a daddy, the desire to play in the area motivated him to think about how to change his role in order to engage in associative play as Piaget's cognitive development theory views children as "busy, motivated explorers whose thinking develops as they act directly on the environment" [4, p.212]. Martin used the dog custom to solve the difficulty or unpleasant situation he faced. For Piaget, children learn to adapt to their environments and as a result of their cognitive adaptations they become better able to understand their world [5]. During the process, these more advanced understandings of the world reflect themselves in the appearance; impel them into new stages of development [5]. For example, when Jack said "Hello, doggy" Martin answered 'Ruff, Ruff' like a dog. They all adapted to the changing of their roles in the play, their cognitive adaptations supporting them build a better understanding on how to involve into a role-play, as well as how to respond constructions from other partners in play. Piaget's theory is therefore a good example of view from which portrays children as "inherently active, continually interacting with the environment, in such a way as to shape their own development" [5, p.22].

Educators who work with developmental theories are interested in "understanding what children are most likely to do at a certain age so that they can plan learning experiences that will support 'typically' occurring development" [2, p.4]. In this aspect, I think through planning a series of child-centered activities based on Martin's interests, educators can support him exploring new behaviors. At this point, playing is not the same as learning but could facilitate learning by exposing Martin to new experiences and new possibilities for acting in and on the world. Moreover, developmental theories were interpreted to imply that educators should create environments in which children could be active learners, free to explore experiment, combine different materials, as well as create and solve problems through their self-chosen, self-directed activities [5]. Thus I think through providing interesting and stimulating materials and resources in the setting for children to use educators can scaffold children's self-control in play which will help them obtain confidence in social, emotional and cognitive development.

\section{Connecting interpretations with EYLF}

Children learn to interact in relation to others with care, empathy and respect. Children develop a sense of belonging to groups and communities and an understanding of the reciprocal rights and responsibilities necessary for active civic participation. Children take increasing responsibility for their own health and physical wellbeing.

\section{B. Socio-Cultural lens}

Vygotsky's socio-cultural theory considers the effect of cultures when looking at child development and child behavior [6]. This theory suggests that social interactions need to be understood as "a part of the cultural setting and not separately in order to understand the contribution of social interaction to cognitive development and thinking" [5, p.29].

Vygotsky thought that mind was inherently dependent on cultural tools or mediated means such as language [7]. Language is central to children's development. Children first use language to communicate with other people, but then their language is converted into internal speech or thought which is used for self regulation [8]. Speech is an essential tool to allow children to plan and carry out actions, deal with things and control their own behavior. For example, Martin responded 'Ruff, Ruff' to Jack instead of 'Hello, Jack' when Jack said "hello, doggy", Martin used the language to deal with the situations and control his behavior to be a 'dog' in the play. Furthermore, Vygotsky [8] also believed language is an important tool for thought and plays a key role in cognitive development. He introduced the term private speech, or selftalk which refers to when children "think out loud." Children engage in this self-talk to help guide their activity and develop their thinking [5]. As described in the observation when Martin looked into the role-play area, he engaged in self-talk rather than ask question like "Can I play here" to show that Martin did not know how to share his meaning in communicative talk.

Vygotsky's concept of the zone of proximal development (ZPD) is a key one in applying his theory to education as scaffolding permitting children to do as much as they can by themselves while what they can not do is filled in by the tutor's activities [9]. Therefore, educators work as instructors, so they can "rely heavily on verbal cues" $[10$, p.76], such as provide suggestions and instructions for children to actively contribute to their own cognitive development by constructing their own understanding of the world. For example, scaffolding Martin to learn how to negotiate with others and how to behave appropriately rather than pushing or punching play partners to get their agreement. Still, I think educators need to know learners well so that they can provide the right level of guidance, and gradually withdraw it as the child comes to understand and perform the task alone. Therefore, educators can through put Martin in a small play group, through observation, interaction and communication with Martin to adjust their support to Martin's current level of understanding.

\section{Connecting interpretations with EYLF}

Children feel safe, secure and supported. Children learn to interact in relation to others with care, empathy and respect. Children become socially responsible and show respect for the environment. Children take increasing responsibility for their own health and physical wellbeing. 


\section{Poststructural lens}

Feminist poststructuralism used to describe "the mechanisms of power and how meaning and power are organized, enacted and opposed in our society" [11, p.119]. Poststructuralism becomes feminist when matters of gender and a commitment to change are of central concern [11], it used by educators for "understanding the complexities of gender in order to create opportunities for equity and justice in all children's lives" [11 p1.19].

Blaise [12] states that poststructuralist concepts offer early childhood educators new ways of seeing gender and sexuality. Poststructuralist concepts also help educators to ask different kinds of questions, and to see other possibilities in what may have become accepted everyday practice. For instance, when Martin said 'There are can be two daddies', what does this mean to him? What identity was he seeking and producing by saying that there are can be two daddies in a family. Lexi said boy can not marry boy, that is not fair' making "calls for teachers to understand and implement more equitable approaches to play in the early years" [13, p.1], Grieshaber and McArdle [13] suggest that play is not always either fun or innocent, and can involve politics and concern itself with morals and ethics. In addition, Ailwood [14] states that early childhood educators should take a critical stance towards play. She insightfully suggests that in disrupting the taken-forgranted practices and the systems that keep them happening and being accepted within our community, using poststructural theory educators can set up regulating frameworks of what is acceptable, what is fair and what is just in children's play [14].

In drawing upon feminist poststructuralism, educators are offered a way of producing new knowledge by "using poststructural theories of language, discourse, subjectivity and agency to understand how power is exercised in the classroom" [11, p.119]. Educators can ask thoughtful questions about their own practice, but in harmony with the children's perspective. If educators heard the dialogue between the three children in the observation, what they should do if they want to actively resist the gendered perspective being put forward. Martin expressed on his perspective indicated that child rights and a child's voice were ever-present, how should educators to react to Martin's voice? Lexi's presentation of two boys can not marry not only reflects the co-creation of social justice issues, but demonstrates how even very young children can engage in social and political issues with great understanding [15]. Thus, this critical incident led educators to understand that children as young as 4 can have firmly held beliefs that become visible in their play, and educators need to have tools to respond to these critical incidents in order to promote social justice [15].

\section{Connecting interpretations with EYLF}

Children develop knowledgeable and confident selfidentities. Children respond to diversity with respect. Children become aware of fairness.

\section{CONCLUSION}

Developmental theory is a key tool for early child care educators; it can provide theoretical bases for educators to understand how children learn in the early years. According to children's ages educators can create physical environments and design play activities based on children's certain stages [1]. Developmental theory positions educators' as experts; they stand back and observe children's behavior so they can use their "judgment to support children's learning and development" [1 1 p.13]. However, I recognize that developmental theory often classify what children are able to do into boxed, there is very sad to defined standards based on social, emotional, cognitive or language outcomes, this is classify children in very limited ways and does not allow for holistically view of what child is capable of doing. Developmental theory works well when used in conjunction with other theories, such as socio-cultural theory, poststructure theory, those theories really help questions universal norms, they help to think about what it is we seeing in term of children's holistically development not just whether they can do this or that by themselves. Socio-cultural theories emphasize "the central role that families and cultural groups play in children's learning and the importance of respectful relationships and provide insights into social and cultural contexts of learning and development" [1, p.11]. It emphasizes that cognitive development is essentially a social process. This is of great importance to educators who have to plan how to teach children with diverse social and cultural backgrounds. Poststructural theory inspires educators to "challenge traditional ways of seeing children, teaching and learning" [1, p.11]. It offers insights into issues of power, equity and social justice in early childhood settings [1, p.11].

Following those understandings, when taken together, I expressed my belief that I will think about what tools different theories provide me so that I can look holistically children capacity participate particular ages. Based on the strengths and limitations I discussed above, in my future teaching, I will use more than one theory to observe children's doing because I will not hope to position children separate from other interactions that goes around them. I believe that to work with children, to question with them.

\section{REFERENCES}

[1] Canberra: Commonwealth of Australia, Belonging, Being and Becoming: The Early Years Learning Framework for Australia. Department of Education, Employment and Workplace Relations for the Council of Australian Governments, 2009.

[2] City of Casey Early Childhood Research Collective, In practice and in theory: a booklet for thinking about the five learning outcomes and the early years learning framework. Media and External Relations, Australian Catholic University: Melbourne, 2012.

[3] T. M. McDevitt, and J. E.Ormrod, Child development: educating and working with children and adolescents. 2nd ed., Upper Saddle River, NJ: Pearson Merrill Prentice Hall,2004.

[4] L.E. Berk,. Child development, 6th ed., Boson: Allyn \& Bacon,2003.

[5] E.Wood, Play, learning and the early childhood curriculum, 3rd ed., London: SAGE Publications Ltd,2013.

[6] P.Cobb, "Where Is the Mind? Constructivist and Sociocultural Perspectives on Mathematical Development", Educational Researcher, Vol.23, pp.13-20,1994.

[7] J.V.Wertsch and P.Tulviste,'L.S.Vygotsky and contemporary developmental psychology", Developmental Psychology, Vol.28, pp.548-557,1992.

[8] L.S.Vygotsky, Mind in Society: the Development of Higher Mental Processes. Cambridge: Harvard University Press, 1978. 
[9] D.Wood, J. S.Bruner, and G. Ross, "The role of tutoring in problem solving", Journal of Child Psychology and Psychiatry, Vol.17, pp.89$100,1976$.

[10] L.M.Flloari,Foundations and best practices in early childhood educationhistory, theories, and approaches to learning, 2nd ed., New Jersey: Pearson, 2011.

[11] G. Latham, M. Blaise, S. Dole, J. Faulkner, and K. Malone, Learning to teach new times, new practices, 2nd ed., Australia \& New Zealand: Oxford University Press, 2011.

[12] M. Blaise, "New maps for old terrain: creating a postdevelopmental logic of gender and sexuality in the early years", in L Brooker \&
Edwards .Eds., Engaging play, Maidenhead: Open University Press, 2010, pp.80-95.

[13] S.Grieshaber and F.McArdle, The trouble with play. Maidenhead: Open University Press, 2011.

[14] J.Ailwood, "Playing with some tensions: poststructuralism, Foucault and early childhood education", in 1 Brooker \& Edwards ,Eds., Engaging play, Maidenhead: Open University Press,2010, pp.210-222.

[15] M.Fleer, Play in the early years. New York:.Cambridge University Press, 2013. 